\title{
New aspects in nonsurgical treatment of Marshall syndrome
}

\section{Aspecte noi în tratamentul nonchirurgical al sindromului Marshall}

\author{
Veronica EPURE ${ }^{1,2}$, Dan Cristian GHEORGHE ${ }^{1,2}$ \\ ${ }^{1}$ Spitalul Clinic de Urgenţă pentru Copii „M.S. Curie“, Bucureşti, România \\ 2 Universitatea de Medicină şi Farmacie „Carol Davila“, Bucureşti, România
}

\begin{abstract}
Marshall syndrome, defined by recurrent fever episodes, angina, adenitis and stomatitis, is frequently encountered in childhood. Medical treatment consists of corticosteroids in order to solve the acute symptoms; adenotonsillectomy or alternative medication can be administered on the long term in order to prevent recurrence of symptoms.

The authors present a case of Marshall syndrome; based on personal experience and data from literature, the authors draw attention on the efficiency of montelukast in preventing recurrence of episodes, as an alternative option to surgery.
\end{abstract}

Keywords: fever, angina, adenitis, montelukast

\begin{abstract}
REZUMAT
Sindromul Marshall - caracterizat prin apariția unor episoade recurente de febră, angină, adenită şi stomatită - se întâlneşte frecvent în patologia pediatrică. Tratamentul medical pe termen scurt presupune administrarea de corticosteriozi pentru cuparea crizelor, iar, pe termen lung, profilaxia acestora prin mai multe tipuri de medicamente sau prin adenoamigdalectomie.

Autorii prezintă un caz clinic de sindrom Marshall, pe baza datelor din experiența personală şi a datelor din literatura de specialitate susținând eficiența administrării de inhibitori de leucotriene în profilaxia pe termen mediu şi lung a episoadelor, ca alternativă la tratamentul chirurgical.
\end{abstract}

Cuvinte cheie: febră, angină, adenită, montelukast

\section{INTRODUCERE}

Episoade recurente de febră, angină acută, stomatită aftoasă și adenită laterocervicală definesc un sindrom de etiologie neprecizată, descris de Marshall în 1987 (PFAPA - periodic fever, aphtous stomatitis, pharyngitis, cervical adenitis) (1). Episoadele febrile debutează de obicei la copilul sub 5 ani și reapar cu re- gularitate la un interval cuprins între 2 și 12 săptămâni $(2,3)$.

În prezent, tratamentul sindromului Marshall se împarte în două direcții: medical și chirurgical. Tratamentul medical presupune pe termen scurt cuparea simptomatologiei în episoadele acute prin administrarea de corticosteriozi și antipiretice (antibioticele și AINS sunt ineficiente), iar, pe termen mediu, preveni- 
rea acestora (autorii străini citează posibilitatea de folosire a cimetidinei, montelukastului, anakinra, colchicină) $(4,5)$. Administrarea sistemică a corticosteroizilor în episodul acut febril, oral sau injectabil, în doză unică sau două doze succesive, duce la rezoluția dramatică a simptomelor, constituind și probă terapeutică pentru stabilirea retrospectivă a diagnosticului de sindrom Marshall $(2,3)$. Dozele de corticoizi recomandate în urmă cu 20 de ani în tratamentul PFAPA sunt mari (6) și dependente de greutatea corporală a pacientului. Ca urmare a efectelor adverse redutabile ale corticoterapiei (4), este de dorit scăderea dozelor până la un minim acceptabil și eficient $(7,8,9)$.

Tratamentul pe termen lung în acest sindrom poate fi chirurgical (adenoamigdalectomia soluționând definitiv crizele febrile recurente) sau medicamentos. Dintre toate alternativele propuse de diverși autori pentru profilaxia recurențelor în sindromul Marshall, administrarea de montelukast pe termen lung pare a fi cea mai simplă și ieftină metodă, cu efecte adverse reduse $(10,11)$.

Montelukastul este un antagonist de receptor pentru cisteinil leucotriene (C4, D4, E4) (mediatori potenți ai inflamației), substanțe sintetizate din acidul arahidonic de celulele mastocite, bazofile, macrofage activate și implicate în reacțiile inflamatorii, care atrag neutrofilele la locul inflamației, cresc permeabilitatea vasculară și produc contracția mușchilor netezi bronșici (11), chemoatracția eozinofilelor, cu eliberarea altor mediatori proinflamatori în cascadă.

Montelukastul este folosit frecvent în tratamentul rinitei alergice și al astmului bronșic, dar, recent, a căpătat și alte indicații de utilizare, datorită proprietăților sale antiinflamatoare aparent nelegate de antagonizarea receptorilor leucotrienici (țintind eozinofilele, monocitele și neutrofilele insensibile la corticosteroizi) (12). Este bine tolerat, administrat odată pe zi, cu profil de siguranță similar în polulația pediatrică și adultă; posibilele efecte adverse sunt rare: cefalee, tulburări gas- trointestinale, hiperactivitate, insomnie la copii, oboseală, apatie ( $1 \%$ dintre cazuri), foarte rar sindrom Churg-Strauss, alterarea parametrilor hepatici $(13,14)$.

Prezentăm în continuare un caz de sindrom Marshall în care utilizarea inhibitorilor de leucotriene pe termen lung a fost eficientă în profilaxia episoadelor febrile; menționăm că avem acordul aparținătorilor pacientei pentru tratamentul instituit, precum și pentru includerea datelor anonimizate ale acesteia în prezentarea de caz.

\section{PREZENTAREA CAZULUI}

Pacienta M.M. s-a prezentat la vârsta de 10 luni în serviciul nostru, cu febră înaltă, adenită laterocervicală, angină acută. Conform anamnezei de la mamă, pacienta prezenta episoade febrile recurente de angină acută eritematoasă sau eritematopultacee cu febră înaltă o dată la 3 săptămâni de la vârsta de 5 luni, fără alte antecedente patologice. Diagnosticul de sindrom Marshall a fost stabilit pe baza anamnezei, a examenului clinic în puseu acut (angină acută eritematoasă sau eritematopultacee cu febră înaltă) și a analizelor de laborator. Pacienta nu a prezentat stomatită, iar adenita laterocervicală a fost inconstantă în timpul episoadelor febrile recurente.

Paraclinic, se constată markeri inflamatori intens pozitivi în puseu (leucozitoză 17.210 elem $/ \mathrm{mm}^{3}, \mathrm{CRP}=$ 247 mg/l; în alt puseu acut leucocitoză 20.000 elem/ $\mathrm{mm}^{3}, \mathrm{CRP}=153 \mathrm{mg} / \mathrm{dl}$ ), intercritic cu valori normale.

Simptomele pacientei s-au ameliorat la fiecare recurență rapid și dramatic după administrarea de dexametazonă (proba terapeutică pozitivă); dexametazona a fost administrată injectabil inițial în alt seviciu medical în două doze a câte $0,5 \mathrm{mg} / \mathrm{kg} /$ doză, apoi - de la preluarea pacientei în urmărire - de 4 mg per doză, oral, în două doze la 24 ore interval (pacientă cu greutate corporală 8,5-10,5 kg). Având în vedere posibilele efecte adverse ale corticoterapiei sistemice, în ultima

\begin{tabular}{|c|c|c|c|c|}
\hline AN002 Ac. anti ADN dublu catenar (cantitativ) & $\mathrm{R} 5,11, \mathrm{M} 2, \mathrm{~A} 2$ & 777.30 & $\begin{array}{l}\text { NEGATIV: } 0-200 \\
\text { SLAB POZITIV: } 201-300 \\
\text { MODERAT POZITIV: } 301-800 \\
\text { INTENS POZITIV: }>800\end{array}$ & $\mathrm{UI} / \mathrm{ml}$ \\
\hline AN020 Ac. antinucleari (ANA/FAN) ${ }^{\circ}$ & $\mathrm{RS}, \mathrm{L1}, \mathrm{A3}$ & 0.5 & $\begin{array}{c}\text { Negativ: }<1.0 \\
\text { Echivoc: } 1.0-1.2 \\
\text { Pozitiv: }>1.2\end{array}$ & Index \\
\hline Al008 Complement seric C3 & $R 1, L 1, M 3, A 6$ & 1.07 & $0.90 \cdot 1.80$ & $B / L$ \\
\hline Al009 Complement seric C4 & $R 1, L 1, M 3, A 6$ & 0.38 & $0.10-0.40$ & $\mathrm{~g} / \mathrm{L}$ \\
\hline Al003 Factor Reumatoid cantitativ & $R 1, L 1, M 3, A 6, D 4$ & 4.40 & $00.00-14.00$ & $\mathrm{Ul} / \mathrm{ml}$ \\
\hline Al096 Imunoglobulina D (IGD) & R3,L2,A3 & 13.00 & $<140$ & $\mathrm{mg} / \mathrm{L}$ \\
\hline Al017 Imunoglobulina IgA & $R 2, L 2, A 1$ & 55.60 & $00.00-83.00$ & $\mathrm{mg} / \mathrm{dL}$ \\
\hline Al019 Imunoglobulina IgG & R2,L2,A1 & 893.20 & $232.00-1411.00$ & $\mathrm{mg} / \mathrm{dL}$ \\
\hline A1020 Imunoglobulina IgM & R2,L2,A1 & 91.10 & $00.00-145.00$ & $\mathrm{mg} / \mathrm{dL}$ \\
\hline Al005 Proteina $\mathrm{C}$ reactiva cantitativa ${ }^{\circ}$ & R2,L2,A1,05 & 22.92 & $00.00-5.00$ & $\mathrm{mg} / \mathrm{L}$ \\
\hline
\end{tabular}

FIGURA 1. Modificări de tip autoimun într-un puseu febril acut 
perioadă încercăm scăderea dozelor de cortizon administrate la pacienții cu sindrom Marshall: 4 mg dexametazonă orală per doză, 2 doze la pacienții cu greutate sub 40 kg sau 8 mg per doză, 2 doze la pacienții cu greutate corporală peste $40 \mathrm{~kg}$.

Menționăm că, în cursul acestor episoade febrile, febra a fost înaltă $\left(39-40^{\circ} \mathrm{C}\right)$, persistentă și greu responsivă la antitermicele uzuale (Ibuprofen, Paracetamol suspensie, Novocalmin supozitoare), necesitând adesea internarea pacientei.

Având în vedere vârsta mică a pacientei, s-a căutat o alternativă la adenoamigdalectomie pentru prevenirea recurențelor febrile; ideea tratamentului cu substanțe imunomodulatoare în acest caz a apărut ca urmare a constatării unor modificări de tip autoimun într-un puseu febril acut (Figura 1).

În colaborare cu medicul pediatru al copilului, s-a instituit tratament cu montelukast $4 \mathrm{mg}$ pe zi per os; după aproape 5 luni de tratament, pacienta prezintă doar trei episoade febrile de intensitate redusă (cu markeri inflamatori în puseu mult reduși față de episoadele anterioare: leucocite $7.720 / \mathrm{mm}^{3}$, CRP $22,6 \mathrm{mg} / \mathrm{l}$ în primul puseu; la al treilea puseu, leucocite $13.800 / \mathrm{mm}$, neutrofilie ușoară $69,6 \%$, leucopenie $28,7 \%$, CRP 69,25 $\mathrm{mg} / \mathrm{l}$; febră $38-38,5^{\circ} \mathrm{C}$ care scade rapid la antitermice, răspuns prompt la dexametazonă orală $4 \mathrm{mg}, 2$ doze; durata episoadelor febrile sub tratament cu montelukast mult redusă).

Se remarcă astfel apariția unor episoade febrile de mai mică intensitate și spațierea semnificativă a acestora (interval intercritic în medie 5 săptămâni sub tratament cu montelukast față de 3 săptămâni înainte).

Pacienta a fost reevaluată clinic și paraclinic la 2 luni de la debutul tratamentului, constatându-se o ușoară creștere a TGO la $81 \mathrm{U} / \mathrm{l}$, în rest constante biologice normale. În prezent, pacienta continuă tratamentul cu montelukast, fără efecte adverse notabile.

\section{DISCUŢII}

Corticosteroizii, chiar dacă eficienți și în doză mică pentru a reduce simptomele în episoadele acute febrile din sindromul Marshall $(8,9)$, nu pot preveni însă recurența acestora; după unii autori, chiar pot scurta inter- valul intercritic (4). Discutând despre tratamentul pe termen lung al sindromului Marshall, adenoamigdalectomia nu este întotdeauna acceptată de către părinții pacienților, în special ai celor cu vârsta sub 2 ani.

Posibilitatea tratamentului cu substanțe imunomodulatoare (anakinra, montelukast) în sindromul Marshall a pornit de la constatarea că în timpul episoadelor acute febrile apare o supraexpresie de citokine proinflamatorii (II-18, IL-6, II-1 $1_{\beta}$ ) și de citokine pentru recrutarea limfocitelor T activate (IP-10/CXCL 10, MIG/ CXCL 9) (14).

Unii autori au constatat că utilizarea montelukastului în tratamentul pe termen lung în sindromul Marshall a dus la mărirea intervalului intercritic dintre episoadele febrile (de exemplu, de la $45-55$ de zile la 55-65 zile) $(10,15)$.

Efectul pe termen lung al tratamentului cu inhibitori de leucotriene în tratamentul profilaxiei recurențelor la pacienții cu sindrom Marshall a fost studiat rar, pe serii mici de pacienți $(10,15)$; un studiu pe un lot de 28 pacienți a arătat o eficiență bună (68\%) și un raport costeficiență bun la utilizarea montelukastului; 17 pacienți au prezentat răspuns complet (dispariția totală a episoadelor febrile sub tratament cu montelukast), 2 pacienți au răspuns parțial (mărirea intervalului intercritic) și 9 au avut lipsă de răspuns la tratament.

Cazul clinic prezentat, deosebit prin vârsta mică a pacientului, a ridicat problema utilizării unor metode alternative de tratament, tratamentul chirurgical nefiind acceptabil. Tratamentul propus la fiecare pacient cu sindrom Marshall trebuie individualizat. Am utilizat cu success montelukastul pe o perioadă de 5 luni, obținând spațierea episoadelor febrile (de la 3 la 5 săptămâni) și apariția unor episoade de intensitate mult redusă. Continuăm monitorizarea pacientului în prezent - este însă prea devreme pentru a trage o concluzie în ceea ce privește eficiența tratamentelor alternative (cu inhibitori de leucotriene) în acest sindrom.

\section{CONCLUZII}

Tratamentul cu montelukast pare a fi o soluție nonchirurgicală pentru evitarea sau spațierea recidivelor în sindromul Marshall, cu un raport cost-eficiență bun.

Conflict of interest: none declared Financial support: none declared

\section{BIBLIOGRAFIE}

1. Marshall GS, Edwards KM, Butler J, Lawton AR. Syndrome of periodic fever, pharyngitis, and aphthous stomatitis. J Pediatr. 1987 Jan;110(1):43-6.

2. Berlucchi M, Meini A, Plebani A, Bonvini MG Lombardi D, Nicolai P. Update on treatment of Marshall's syndrome (PFAPA syndrome): report of five cases with review of the literature. Ann Otol Rhinol Laryngol. 2003 Apr;112(4):365-9.

3. Feder HM Jr. Periodic fever, aphthous stomatitis, pharyngitis, adenitis: a clinical review of a new syndrome. Curr Opin Pediatr. 2000 Jun;12(3):253-6.
4. Scimeca PG, James-Herry AG, Weinblatt ME. Atypical PFAPA syndrome (periodic fever, aphthous stomatitis, pharyngitis, adenitis) in a young girl with Fanconi anemia. J Pediatr Hematol Oncol. 1996 May;18(2):159-61. 
5. Lierl MB. Efficacy of montelukast for treatment of periodic fever with aphtous stomatitis, pharyngitis and cervical adenitis syndrome. J Allergy Clin Immunol. 2008;121(2)

6. Padeh S, Brezniak N, Zemer D, Pras E, Livneh A, Langevitz P, Migdal A, Pras M, Passwell JH. Periodic fever, aphthous stomatitis, pharyngitis, and adenopathy syndrome: clinical characteristics and outcome. J Pediatr. 1999 Jul;135(1):98-101.

7. Nadim NH, Nasir N, Habib MG, Samra NG. The lowest dose of corticosteroids, which stops the episodes of PFAPA syndrome. Australasian Medical Journal. 2017 May;10(4):322-328.

8. Epure V. Effectiveness Of Low-Dose Corticosteroids in The Treatment of Marshall Syndrome - Case Report. IJCMCR 2020;9(3):002.
9. Yazgan H, Gültekin E, Yazıcılar O, Sagun ÖF, Uzun L. Comparison of conventional and low dose steroid in the treatment of PFAPA syndrome: preliminary study. Int J Pediatr Otorhinolaryngol. 2012 Nov;76(11):1588-90.

10. Mertz TL, Prematta T, Ishmael F, Groh BP. Case Series of the Effectiveness of Montelukast for Periodic Fever Syndromes, J Allergy Clin Immunol. Feb 2011;127(2).

11. Benninger MS, Waters H. Montelukast: Pharmacology, Safety, Tolerability and Efficacy. Clinical Medicine Insights: Therapeutics. 2009 Sep;1:1253-1261.

12. Tintinger GR, Feldman C, Theron AJ, Anderson R. Montelukast: more than a cysteinyl leukotriene receptor antagonist? ScientificWorldJournal. 2010 Dec 14;10:2403-13.

13. Riccioni G, Di llio C, Conti P, Theoharides TC, D'Orazio N. Advances in therapy with antileukotriene drugs. Ann Clin Lab Sci. 2004 Autumn;34(4):379-87.

14. Stojanov S, Lapidus S, Chitkara P, Feder H, Salazar JC, Fleisher TA, Brown MR, et alL. Periodic fever, aphthous stomatitis, pharyngitis, and adenitis (PFAPA) is a disorder of innate immunity and Th1 activation responsive to IL-1 blockade. Proc Natl Acad Sci U S A. 2011 Apr 26; 108(17):7148-53.

15. Abolghasemi S, Atashi HA, Paydar-Tali E, Olya M, Zaferani-Arani H. The First Case of Adult-Onset Periodic Fever, Aphthous Stomatitis, Pharyngitis, and Adenitis Syndrome with Splenomegaly in Iran. Caspian J Intern Med. 2019 Spring; 10(2):231-234. 